\title{
STUDY ON PHYSICO-CHEMICAL PARAMETERS OF LONAR CRATER LAKE, INDIA
}

Dabhade D. S. and Tandale M. R.

P.G. Department and Research Laboratory of Zoology,

R.A. Arts, M .K. Commerce and S .R. Rathi Science College, Washim.444 505 M.S. India.

dsdabhade12345@gmail.com

\begin{abstract}
:
To understand Water quality of any ecosystems we most know about their different physico-Chemical parameters. Lonar is best aquatic ecosystems for the understanding of quality of lake water because it is Magic water. Such Crater Lake is situated inBuldana district of Maharashtra state India. Lonar Lake is the third largest natural saltwater lake in the world. Present work on analyze Physico chemical parameters and investigate the pollution level so as to determine status of eutrophication of Lonar Crater. Lonar Crater is a wet land which is important biodiversity sector. The lake brine supports typical microbial flora and fauna need to be investigated to access its value of wet-land to be recognized as Ramsar Site of India. For the investigation of water quality, we selected four different sites to analyzed Physical parameters like Temperature, Colour by means of Transparency, Total dissolved Solid and Electrical conductivity along these physical several Chemical parameters also studied that is Dissolved oxygen, Alkalinity on the basis of both Carbonate and Bicarbonates, Chloride, Salinity, Calcium and their Hardness, Magnesium Hardness, Phosphate, Sulphate, Silicates, Iron, Ammonia, Nitrites, Nitrates, BOD (Biological Oxygen Demand) and COD (Chemical Oxygen Demand) for a one year during January 2014 to December 2014. During the study period it was concluded overall salinity was Decreases and biological oxygen demand increases that may lead towards the Eutrophication.
\end{abstract}

Keyw ords: Physico-Chemical, Parameter, Lonar Lake

\section{Introduction:}

Lonar crater is third biggest due to meteoritic impact crater in the world. The Lonar ecosystem has evolved in a unique way due to the unusual geohydrological and climatic conditions. However, the same conditions have made it extremely fragile and vulnerable to human interventions. Therefore, the biotic zones resulting from such isolation need immediate protection Malu (2002), Kodarkar, (2008), Tandale, Dabhade (2016). Hagerty and Newsom (2001) also suggested that the Lonar crater was formed by the impact of a meteorite. Lonar crater the only such in the great basaltic province of India. The Lonar crater has attracted the attention of world geologists for investigation of its origin and the source of salinity of lake water; it is ecological wonder (Malu et al., 2007). This inland lake with no effluent is fed by a seasonal drainage mainly confined to its periphery and also by number of fresh water springs Dabhade (2015), Tandale and Dabhade (2014). The crater contains many subecosystems, each constituting a subtle combination of floral and faunal species, due to localized variations in the conditions of soil, water and humidity. However, the same conditions have made it extremely fragile and vulnerable to human interventions. Therefore, the biotic zones resulting from such isolation need immediate protection Dabhade (2006). During the experimental periods PhysicoChemical parameters of lake water investigated. On the basis of physicochemical parameters we determine the quality of water and status of that ecosystem. Lonar Lake is very popular for its high Salinity as well as Alkalinity. In case of fresh water bodies there physicochemical parameters are generally in permissible limit due to that it may use full for Drinking purposes as well as Irrigation also Tandale et al., (2012), but some water bodies may not be use full for such purposes then that water body need to conserved the water properly Solanke and Dabhade (2016), Meena et al., (2014), Wanjari (2016) also studied the physico chemical parameters of Kurala Dam for monitoring the load of pollution. Water pollution is due the increasing load of aquatic planktons which can enhance the biological oxygen demand; in case of Lonar crater algae like spirulina was dominant Dabhade and Tandale (2016), Wanjari and Dabhade (2015). Rather than these algae some more planktonic communities study by Dabhade and Tandale (2016).

\section{Material and Methods:}

Lonar Crater (19० 58' $N$ and $\left.76^{\circ} 31^{\prime} E\right)$ Lake is a unique meteoritic crater in basaltic rock. It lies in a nearly circular depression surrounding on all sides by steeply rising escarpments. The lake basin is closed on all sides and therefore has no outlet. Lonar Lake has a localized temperature system as it is being subterranean hollow closed from all sides; the lake basin is partly screened from direct sun light at different places and at different times of the day Dabhade, (2006), Dabhade (2013). 
the periods of One Year (Jan 2014 to Dec 2014). Water Temperature analyzed by simple thermometer, TDS analyzed by the EC-TDS ANALYSER CM 183 ELICO, EC analyzed by Conductivity meter CM-180 ELICO, Total Hardness, Free $\mathrm{CO}_{2}$, Carbonates, Bicarbonates, Chloride, Salinity, Calcium, Calcium Hardness, and Magnesium Hardness, Total Phosphate,
Sulphates, Silicates, Ammonia, Nitrites, Nitrates by using ELICO Nephelometer CL 52D and Spectrophotometer 106 SYSTRONIC by using photometric method, BOD, COD analyzed by Titrometric method with the help of standard method for water analysis (APHA) by Clesceri et al., (1998)

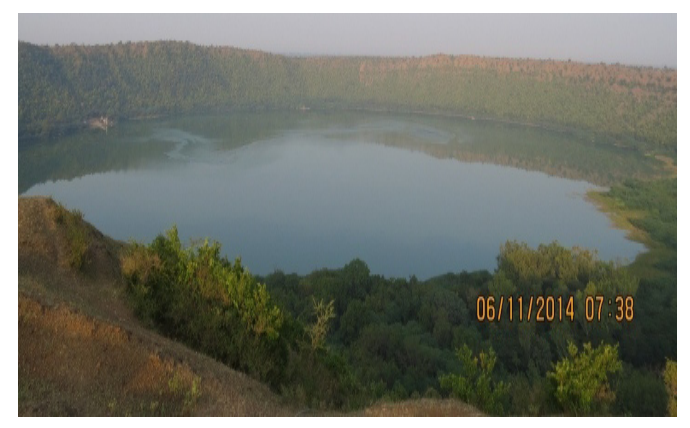

Fig. 1-View of Lonar Lake.

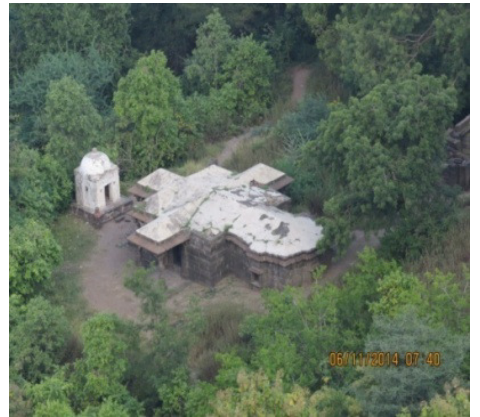

Fig.2-Sampling Site S1 Ramgaya

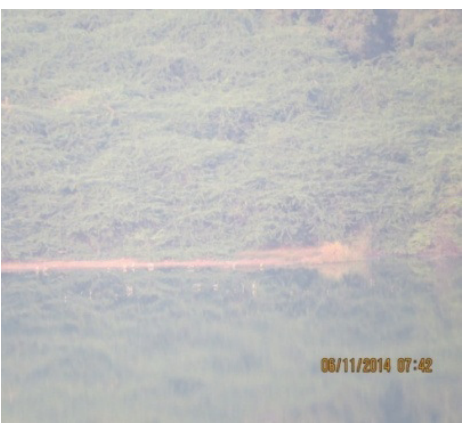

Fig.4-Sampling Site S3 Mahadev Temple

\section{Result and Discussion:}

Physico-Chemical parameters of Lonar crater were studied for one year from four sampling sites, the mean values of all physicochemical parameters are in Table No. 1.

Details of all parameters are given bellow Temperature: During the experimental periods it was observed that highest value of temperature was $27.58 \pm 2.19{ }^{\circ} \mathrm{C}$ on sampling sites $\mathrm{S} 4$, while lowest was observed on $\mathrm{S} 1$ that is $25.25 \pm 2.42$. Lonar Lake is subterranean hollow closed just

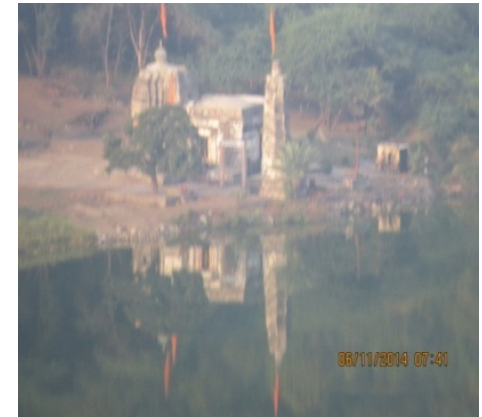

Fig.3-Sampling Site S2 Kamlajadevi Temple

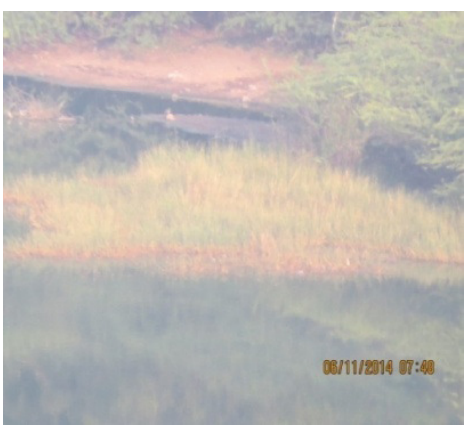

Fig.5-Sampling Site S4 near Dergha

only screening of sunlight at different places and at different times Dabhade, (2006). On the basis of water temperature dissolved form of oxygen may fluctuated Tandale and Dabhade (2016) maximum value of DO (Dissolved Oxygen) were observed on sampling sites S4 and lowest was on $\mathrm{S} 3,4.8 \pm 3.66 \mathrm{mg} / 1$ and $4.02 \pm 2.55 \mathrm{mg} / 1$. Now adays DO of water bodies goes on decreases Dabhade (2013).

Total Hardness of Lake water highest was observed on sampling sites S1 $84.83 \pm 35.3 \mathrm{mg} / 1$ and lowest was $76 \pm 12.7 \mathrm{mg} / 1$ on $\mathrm{S} 2$. Lonar Lake 
water has alkalinity but it was observed that it goes on decreases, the alkalinity of water is due to the absences of free $\mathrm{CO}_{2}$ that may converted in to the Carbonate as well as bicarbonate.

When the value of carbonate was high on sampling sites $\mathrm{S} 1$ then value of Bicarbonate was low and when the Carbonate value low the Bicarbonate value high at sampling sites S2 their values are $1695 \pm 887.5 \mathrm{mg} / 1$ and $1537.17 \pm 833.2 \mathrm{mg} / 1$. Bicarbonates was $1284.17 \pm 554.3 \mathrm{mg} / 1$ and $1207 \pm 505.5 \mathrm{mg} / 1$.

Several solids particles are observed in dissolved form in to the water, maximum of them are ions or others which are not easily separated by simple filtration such particles are called dissolved solids. Total dissolved solids of Lonar water sample highest was observed on S4 which was $7.45 \pm 0.76$ ppt and lowest was on S2 $7.24 \pm 1.00 \mathrm{ppt}$. on the basis of such dissolved ionic component and others they show Electrical conductivity, highest EC(Electrical conductivity) was observed on sampling sites $\mathrm{S} 1$ and lowest was on S2 these are $12.71 \pm 3.44 \mathrm{mS}$, $12.43 \pm 3.37 \mathrm{mS}$.from that it was cleared that the EC of Lonar crater water sample was nearly equal from all sampling sites Tandale and Dabhade (2014).

During the study period minimum chloride was $4162.4 \pm 979.36 \mathrm{mg} / \mathrm{L}$ on $\mathrm{S} 4$ and maximum was in S2 $4659.8 \pm 1297.9 \mathrm{mg} / \mathrm{L}$. Permissible value of chloride is $250 \mathrm{mg} / \mathrm{l}$, Gaikwad and Sasane (2013) also studied the effect of high chloride in water cause laxative effect.

From the Chloride salinity may be calculated if it was in permissible level but in Lonar water sample highest mean value was recorded on the sampling sites S2 $8489.48 \pm 2353.7 \mathrm{mg} / 1$ and lowest was on S4 $7576.93 \pm 1769 \mathrm{mg} / 1$. Borul (2012) was recorded salinity from $8460 \mathrm{mg} / \mathrm{L}$ to $10250 \mathrm{mg} / \mathrm{l}$. From that it was cleared that the value of salinity day by day decreases.

Water sample containing Calcium observed on S2 was highest while on S3 it was low it was $39.7 \pm 24 \mathrm{mg} / 1$ and $36.5 \pm 15.7 \mathrm{mg} / 1$. and hardness was same at sampling sites there values are $9.9 \pm 6 \mathrm{mg} / 1$ and $9.1 \pm 4 \mathrm{mg} / 1$. From the Calcium hardness we may calculate the Magnesium hardness which was observed highest on $\mathrm{S} 1$ and Lowest on $\mathrm{S} 2$ it was $18.3 \pm 8.7 \mathrm{mg} / 1$, $16.1 \pm 3.1 \mathrm{mg} / 1$.

Phosphates is also important element of aquatic ecosystem during the study periods highest value of phosphate was found in $2.62 \pm 1.7 \mathrm{mg} / 1$ and lowest was $1.6 \pm 1.34 \mathrm{mg} / 1$ on sampling site $\mathrm{S} 1$ and $\mathrm{S} 4$ respectively. The values of Phosphates in Natural water was may found higher level due to the contribution of
Sulphates by weathering of the rocks. Due to surface water runoff, agriculture run off, washer man activities increases inorganic phosphate in water in rainy season therefore phosphate level increases in monsoon season. Similar results obtain by Borul (2012), Pawar (2010) observed phosphates value less than $0.82 \mathrm{mg} / \mathrm{L}$. Siddiqi (2008) Reported total phosphates in to the range of $2.8-2.9 \mathrm{mg} / \mathrm{L}$ indicating good biotic utilization by the variety of aquatic biotic life forms and that it is not a limiting factor to biological growth in Crater Lake and such phosphates indicate eutrophication trends in Crater Lake. Satyanarayan et al., (2008), Verma et al., (2013) Yannawar et al., (2013) observed the value more on same fresh water bodies. High amount of Phosphates values acts as nutrition to the several algal species due that they grow vigorously on the surface of water bodies by that biological oxygen demand increases and such lake may move towards the Eutrophication Tandale and Dabhade (2016).

Sulphates are also one of the most important elemental compounds which were runoff from the domestic sewage and also contribute Sulphates to an aquatic ecosystem. During the study period's highest value was observed on sampling sites $\mathrm{S} 4$ which was $1.66 \pm 1.32 \mathrm{mg} / 1$ and lowest was on S1 $0.71 \pm 0.34 \mathrm{mg} / 1$. High level of Sulphates is an indication of pollution Tandale and Dabhade (2014). Sulphates value in Lonar crater was increases on sampling sites S4 due to the flow of sewage water from Lonar town.

During the study periods high value Silicates was observed on $0.89 \pm 2 \mathrm{mg} / 1$ on $\mathrm{S} 4$ and lowest was on $\mathrm{S} 3$ it was $0.31 \pm 0.3 \mathrm{mg} / 1$. In general natural water bodies it was ranges from 1 to 30 $\mathrm{mg} / 1$, as compared to it Lonar water have very less we called it in trace amount. Several rocks and natural water contain very high value of silicates. Iron is one of the most important trace elements in biological system. In Ground Water it was found in Ferrous Bicarbonate form due to oxidation and alkalinity of lake water Tandale and Dabhade (2014). During the study periods highest value was observed on sampling site S2 it was $2.7 \pm 1.33 \mathrm{mg} / 1$ and lowest was $2.16 \pm 1.4 \mathrm{mg} / 1$ on $\mathrm{S} 3$. Nitrogen is the one of the important element which was observed in both Inorganic as well as organic form. Inorganic forms of Nitrogen are Ammonia, Nitrates and Nitrites and organic Form of Nitrogen like Urea, Nucleic acid and amino acid. If both organic forms of Nitrogen and phosphorous show their impact for increasing high BOD byDabhade (2013). 
Ammonia is dissolved in a water to produce Ammonium hydroxide and further dissociates in to Ammonium and hydroxyl ions. Aquatic autotrophs incorporate nitrogen through ammonium ions at a faster rate. During the study period highest value of Ammonia was found $12.1 \pm 9.2 \mathrm{mg} / 1$ on S4 while on S3 it was $8.22 \pm 4.28 \mathrm{mg} / 1$. During the study period's highest value of Nitrites recorded in the S2 was $6.63 \pm 4.34 \mathrm{mg} / 1$ and lowest was on S4 it was $4.025 \pm 3.43 \mathrm{mg} / 1$. Shinde, et al., (2013) Nitrites are found in traces amount but their value was slightly increases during study periods.

During study period Highest value of Nitrates was

Table No. 1. Show Mean and standard deviation Physico Chemical Parameter of four sampling sites.

\begin{tabular}{|l|l|l|l|l|l|}
\hline Parameter & \multicolumn{1}{|c|}{ S1 } & \multicolumn{1}{|c|}{ S2 } & \multicolumn{1}{c|}{ S3 } & \multicolumn{1}{|c|}{ S4 } & \multicolumn{1}{c|}{ total } \\
\hline Temperature & $25.25 \pm 2.42$ & $25.92 \pm 2.2$ & $26.67 \pm 2.14$ & $27.58 \pm 2.19$ & $4.34 \pm 0.53$ \\
\hline DO & $4.125 \pm 2.72$ & $4.43 \pm 2.54$ & $4.02 \pm 2.55$ & $4.8 \pm 3.66$ & $79 \pm 9.92$ \\
\hline Total & $84.83 \pm 35.3$ & $76 \pm 12.7$ & $79 \pm 16.4$ & $76.2 \pm 19.9$ & $1639.13 \pm 55.7$ \\
\hline CO3 & $1695 \pm 887.5$ & $1537.17 \pm 833.2$ & $1650.17 \pm 751.9$ & $1674.17 \pm 826.42$ & $1245.21 \pm 41.6$ \\
\hline HCO3 & $1207 \pm 505.5$ & $1284.17 \pm 554.3$ & $1259.5 \pm 453.84$ & $1230.21 \pm 518.94$ & $7.318 \pm 0.136$ \\
\hline TDS & $7.3 \pm 1.1$ & $7.24 \pm 1.00$ & $7.315 \pm 0.90$ & $7.45 \pm 0.76$ & $12.55 \pm 0.22$ \\
\hline EC & $12.71 \pm 3.44$ & $12.43 \pm 3.37$ & $12.565 \pm 3.38$ & $12.50 \pm 2.96$ & $4482.58 \pm 148.2$ \\
\hline CLOR & $4498.47 \pm 1062$ & $4659.8 \pm 1297.9$ & $4609.63 \pm 990.8$ & $4162.4 \pm 979.36$ & $81.67 .38 \pm 265.9$ \\
\hline SALI & $8202.68 \pm 1958.6$ & $8489.48 \pm 2353.7$ & $8400.44 \pm 1813.3$ & $7576.93 \pm 1769.32$ & $38.2 \pm 5$ \\
\hline CA & $39.06 \pm 16.42$ & $39.7 \pm 24$ & $36.5 \pm 15.7$ & $37.6 \pm 25.3$ & $9.53 \pm 1.24$ \\
\hline CAH & $9.75 \pm 4.1$ & $9.9 \pm 6$ & $9.1 \pm 4$ & $9.4 \pm 6.32$ & $17 \pm 2.54$ \\
\hline MGH & $18.3 \pm 8.7$ & $16.1 \pm 3.1$ & $17.04 \pm 4$ & $16.3 \pm 4.13$ & $2.1 \pm 0.2$ \\
\hline PHS & $2.62 \pm 1.7$ & $2.06 \pm 1.32$ & $2.01 \pm 1.6$ & $1.6 \pm 1.34$ & $1.18 \pm 0.41$ \\
\hline SUL & $0.71 \pm 0.34$ & $1.2 \pm 0.8$ & $1.14 \pm 0.64$ & $1.66 \pm 1.32$ & $0.51 \pm 0.9$ \\
\hline SIL & $0.409 \pm 0.28$ & $0.437 \pm 0.34$ & $0.31 \pm 0.3$ & $0.89 \pm 2$ & $2.41 \pm 0.057$ \\
\hline IRON & $2.47 \pm 1.45$ & $2.7 \pm 1.33$ & $2.16 \pm 1.4$ & $2.33 \pm 1.32$ & $9.95 \pm 2.47$ \\
\hline NH3 & $10.8 \pm 5.4$ & $8.72 \pm 3.70$ & $8.22 \pm 4.28$ & $12.1 \pm 9.2$ & $5.625 \pm 0.8$ \\
\hline NITRI & $5.325 \pm 5.05$ & $6.63 \pm 4.34$ & $6.52 \pm 5.11$ & $4.025 \pm 3.43$ & $9.80 \pm 0.96$ \\
\hline NITRA & $10.58 \pm 9.03$ & $9.81 \pm 7.24$ & $10.31 \pm 9.22$ & $8.52 \pm 7.76$ & $171.56 \pm 6.86$ \\
\hline BOD & $157.083 \pm 98.8$ & $179.58 \pm 96.8$ & $167.08 \pm 97.19$ & $182.5 \pm 111.2$ & $313.21 \pm 11.14$ \\
\hline COD & $311 \pm 124.0$ & $299.58 \pm 112.8$ & $323.08 \pm 115.9$ & $319.17 \pm 137.73$ \\
\hline
\end{tabular}

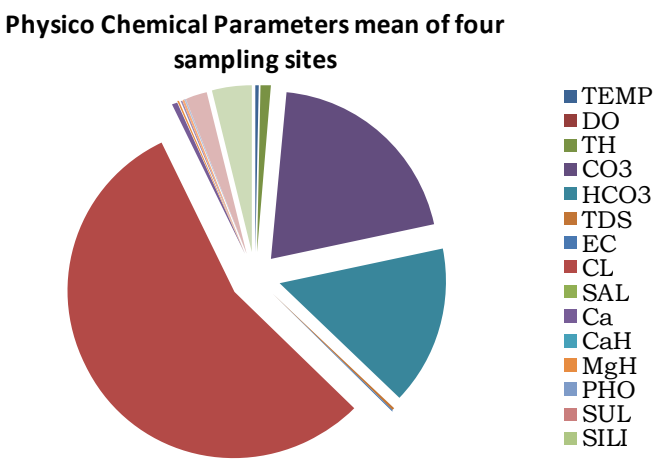

Graph 1. Pia diagram showing mean values of all Physico-Chemical parameters.

\section{Conclusion:}

Lonar Crater Lake is a wet land of important biodiversity. It is extremely important for waterfowls, ducks, cranes, and many other migratory birds and microscopic organis ms. The hydrological study reveals deteriorating changes of flora fauna and macrophytes and increase in observed on $\mathrm{S} 1,10.58 \pm 9.03 \mathrm{mg} / 1$ and lowest was on $\mathrm{S} 4,8.52 \pm 7.76 \mathrm{mg} / 1$. It was gradually increases Dabhade, (2006). During the study periods highest value of BOD was observed on sampling sites $182.5 \pm 111.2 \mathrm{mg} / 1$ on $\mathrm{S} 4$ and $157.083 \pm 98.8 \mathrm{mg} / 1$ on $\mathrm{S} 1$ which was low. While the COD was highest on sampling sites S3 and lowest was on S2 these are $323.08 \pm 115.9 \mathrm{mg} / 1$, $299.58 \pm 112.8 \mathrm{mg} / 1$. In some sewage water also show the high values of both Wanjari and Wanjari (2016). From these values of BOD and COD it was cleared that Lonar lake water was going towards the processes of Eutrophication.

leading towards Eutrophication led to reduction 
to be investigated to access its value of wet-land to be recognized as Ramsar Site of India.

\section{Recommendations and Suggestions:}

It is intensive need of conservation of Lonar lake because of its uniqueness regarding many aspects i.e. Morphometry, Origin, Salinity, Alkalinity, Biodiversity, Geological setting, Topography, Ecology. All the above stated aspects indicating that the lake is not a ordinary occurance in India. Unfortunatelly such a ecological wonder is threatened by anthropological interventions. Due to that conservation should be taken for such ecological wonder.

\section{Acknowledgements:}

We are thankful to Principal investigator Dr. D.S. Dabhade, Professor and head department of Zoology, R.A. Arts, M .K. Commerce and S .R. Rathi Science College, Washim. (MS). for encouraging research and providing laboratory facilities. This research paper is a outcome of Major Research Project sanctioned to Dr. D. S. Dabhade therefore we are grateful to UGC for providing generous financial assistance for Major Research Project.

\section{References:}

Borul, S.B. (2012): Study of water quality of Lonar Lake,Journal of chemical and pharmaceutical research, vol. 4(3): 1716-1718.

Clesceri L.S., Greenberg A.E. and A.D. Eaton (1998): Standard Methods for the Examination of water and wastewater $20^{\text {th }}$ Edition (APHA).

Dabhade D.S. (2013): Eutrophication, A Threat To Saline Lake In A Crater At Lonar, Maharashtra., Asian Journal of Contemporary Sciences, Vol. 2 (1),.1-6.

Dabhade D.S. (2015): Lonar Saline Lake, India-A Case Study. (ICSTS 2015)International Journal Of Researches in Biosciences, Agricultuer and Technology. Vishvashanti Multipurpose Society, Publication IJRBAT, Issue (3) Volume II. May 2015. 249-241.

Dabhade D. S., M. R. Tandale (2016): Quantitative analysis of Zooplankton Communities of Meteorite impact Crater Lonar, India. Journal of Research Journey International Multidicipilinary E- Research Journal, Vol. Special Issue (4), 98-104.

Dabhade D.S., M.R. Tandale (2016): Some more planktons of Lonar crater Lake, India. International Interdisciplinary Research Journal, ISSN 2319-4979, 189-193.

Dabhade, D.S. (2006): Limnological studies on Lonar Crater Lake, Maharashtra. Ph.D. Thesis submitted to S.G.B. Amravati University, Amravati.

Gaikwad, R.W. and Sasane, V.V. (2013): Assessment

of ground water quality in and around Lonar Lake and possible water treatment. International journal of environmental sciences, Vol. 3(4).
Hagerty, J.J. and H.E. Newsom (2001): New evidence for impact-induced hydrothermal alteration at the Lonar Crater, India: Implications for the effect of small craters on the mineralogical and chemical composition of the Martian regolith. Lunar and Planetary Science 32, Abs. No. 1131. J. Chem. Pharm. Res., ISSN No: 0975-7384, 2(4):225-231.

Kodarkar, M.S. (2008): Conservation and Management of Lakes Case Studies from India. Proceedings of Taal 2007, The 12th World Lake Conference: $1442-1445$.

Lake Conference: 1597-1613.

Malu, R.A. (2002): Lonar crater saline lake, an ecological wonder in India, http://www.isslr.org/news/newsone.asp?qnewsid=18 8.

Malu, R.A., Dabhade, D.S. and Kodarkar, M.S. (2007): Conservation and management of Lonar Lake, An Ecological Wonder, Maharashtra, India. World Lake Vision-Action report, International Lake Environment Committee Foundation (ILEC), Japan, 208-216.

Meena L., Kuldeep B. L., Nama P. and M. $R$. Tandale (2014): Phytoplankton study of Jhalamand pond with special reference to their seasonal variation. Journal Of Global Biosciences Vol. 2(4), 2013, 71-78 Http://Mutagens.Co.In/Jgb.Html.

Pawar A.L. (2010): Seasonal Variation in Physicochemical quality of Lonar Lake Water. journal of chemical and pharmaceutical research. Vol 2(4), 225-231.

Satyanarayan, S., P.R. Chaudhari and S. Dhadse (2008):Limnological Study on Lonar Lake: A Unique Brackish Crater Lake in India Sengupta, M. and Dalwani, R. (Editors). Proceedings of Taal 2007: The $12^{\text {th }}$ World Lake Conference: 2061-2066.

Shinde, V.A. and More, S.M. (2013): Study of Physicochemical Characterization of Lonar Lake Effecting Biodiversity Lonar Lake, Maharashtra, India. International Research Journal of Environment Sciences Vol. 2(12), 25-28.

Siddiqi, S.Z. (2008): Limnological profile of highimpact meteor crater Lake Lonar, Buldana,Maharashtra, India, an extreme hyperalkaline, saline habitat. Proceedings of Taal2007: The 12th World

Solanke M.R., D.S. Dabhade (2016): PhysicoChemical Analysis of Upper Morna Reservoir, Medsi, District Washim, Maharashtra. Multidisciplinary Research Journal: Indian Stream Research Journal, Vol. 5(12), Jan, 89-99.

Tandale M.R., D.S. Dabhade (2014): Study OnPhysico-Chemical Parameter Of Lonar Crater India. Bioscience Biotechnology Research Communications: VOL. 7(1), 50-16.

Tandale M. R. and D.S. Dabhade (2014): Study on some physico-chemical parameter of lonar crater India. Journal of Global Biosciences Vol. 2(4), 2013, 71-78 Http:/ / Mutagens.Co.In/Jgb.Html.

Tandale M. R., D. S. Dabhade (2016): Study on Chemical Parameter of Meteorite Impact Crater Lake Lonar, India Multidisciplinary Research Journal: Indian Stream Research Journal, Vol. 5(12), Jan, 105111. 
Tandale M.R., D.S. Dabhade, S.N. Tayade (2012). A Study on Physico-Chemical Parameter of Ekburji Reservoir, Washim, M.S., National conference on Resent trends in biosciences. ISBN 978-81-922866-17, 348-355

Tandale M.R., D.S. Dabhade (2014): Study on chemical parameter of Lonar crater India. The National Academy of Sciences, India.

Verma, $\mathbf{S}$ R and Chaudhari, PR (2013): Limnological Studies on Indian Brackish Water Lonar Lake with Special Reference to Trophic Status and Potential Public Utility,Research Journal of Chemistry and Environment,Vol.17 (4)

Wanjari A.J. , H.V. Wanjari (2016): A study on the Sewage disposal and quality status of Khuni river near Pandharkawada, India, International Interdisciplinary Research Journal, ISSN 2319-4979, 316-318.
Wanjari H.V. (2016): Limnological study of Kurala Dam of Washim district, Maharashtra, International Journal of applied Research, www.allresearchjournal.com, Vol. 2(7), 491-494.

Wanjari H.V. and D.S. Dabhade ( 2015): Lonar Crater Lake of India: An Abundant Source of Highly Economic Important Spirulina; ICSTS (2015) International Journal Of Researches in Biosciences, Agricultuer and Technology. Vishvashanti Multipurpose Society, Publication IJRBAT, Issue (3) Vol. 2 May, 249-241.

Yannawar, V.B. and Bhosle A.B. (2013): Cultural Eutrophication of Lonar Lake, Maharashtra, India, International Journal of Innovation and Applied Studies Vol. 3 (2), 504-510. 